\title{
Effect of stocking density on performance, carcass yield, productivity, and bone development in broiler chickens Cobb 500 ${ }^{\circledR}$
}

\section{Efeito da densidade de criação sobre o desempenho, rendimento de carcaça, produtividade e desenvolvimento ósseo de frangos de corte Cobb 500 ${ }^{\circledR}$}

\author{
Cleoneide dos Santos Henrique ${ }^{1 *}$; Andréia Fróes Galuci Oliveira ${ }^{2}$; Thales Silva \\ Ferreira $^{3}$; Eduardo Santos Silva ${ }^{3}$; Bruna Finotti Fonseca Reis de Mello ; Agner de \\ Freitas Andrade ${ }^{3}$; Vinícius da Silva Freitas Martins ${ }^{3}$; Fernando Oliveira de Paula ${ }^{3}$; \\ Elis Regina de Moraes Garcia ${ }^{4}$; Luís Daniel Giusti Bruno ${ }^{5}$
}

\begin{abstract}
This study aimed to assess the effect of stocking density of $10,12,14$, and 16 birds $\mathrm{m}^{-2}$ on performance, carcass and cut yields, productivity, and bone development of broiler chickens Cobb $500^{\circledR}$. The experimental design was completely randomized design with four treatments (stocking densities) and four replications. The assessments were performed weekly at 1, 7, 14, 21, 28, 35, and 42 days. The best live weight result was found at a density of 10 birds $\mathrm{m}^{-2}$ in the period from 1 to 7 days. No effect of density was observed on feed intake and weight gain. From 1 to 14 days, the best live weights were

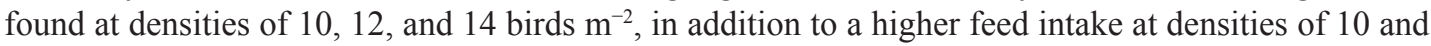
12 birds $\mathrm{m}^{-2}$. Weight gain was better at a density of 10 birds $\mathrm{m}^{-2}$, showing no differences from densities of 12 and 14 birds $\mathrm{m}^{-2}$. In the period from 1 to 21 days, live weight and weight gain were higher at densities of 10,12 , and 14 birds $\mathrm{m}^{-2}$. The highest feed intake was observed at a density of 10 birds m $\mathrm{m}^{-2}$,

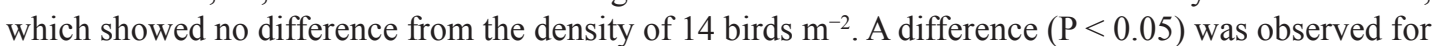
live weight, weight gain, and feed intake of animals reared at densities of 10, 12, and 14 birds $\mathrm{m}^{-2}$ for the phases from 1 to 35 days and the total phase from 1 to 42 days of bird age when compared to 16 birds $\mathrm{m}^{-2}$, which presented lower performance. However, feed conversion of 1-7, 1-14, 1-21, 1-35, and 1-42 days and carcass and cut characteristics showed no significant differences for all treatments. On the other hand, productivity was higher in the treatments with 14 and 16 birds $\mathrm{m}^{-2}$, but without difference between each other. No interaction $(\mathrm{P}>0.05)$ was observed between stocking density and age for the assessed bone parameters. Similarly, no difference $(\mathrm{P}>0.05)$ was observed for bone development of broiler chickens reared at different stocking densities for the studied parameters. Thus, the increased density of 10 or 12 birds $\mathrm{m}^{-2}$ to 14 birds $\mathrm{m}^{-2}$ has no influence on zootechnical performance, carcass and cut yields, and bone development, but increases broiler chicken productivity reared in a conventional shed without air conditioning.
\end{abstract}

Key words: Cobb $500^{\circledR}$. Femur. Live weight. Breast meat yield. tibia.

\footnotetext{
M.e, em Agronomia, Universidade Estadual de Mato Grosso do Sul, UEMS, Cassilândia, MS, Brasil. E-mail: cleo.sh@hotmail. com

2 Prof $^{a}$ Dr $^{\mathrm{a}}$, UEMS, Cassilândia, MS, Brasil. E-mail: galuci@uems.br

3 Discentes, Graduação em Agronomia, UEMS, Cassilândia, MS, Brasil. E-mail: thalessferreira@hotmail.com; edu.passolongo@ gmail.com; bff.mello@hotmail.com; agner_freitas@hotmail.com; vinicius_s_freitas@hotmail.com; fernando-oliveira13@ hotmail.com

4 Prof ${ }^{\mathrm{a}} \mathrm{Dr}^{\mathrm{a}}$, UEMS, Aquidauana, MS, Brasil. E-mail: ermgarcia@uems.br

5 Prof. Dr., Universidade Estadual do Oeste do Paraná, UNIOESTE, Marechal Cândido Rondon, PR, Brasil. E-mail: luis.bruno@, unioeste.br

* Author for correspondence
} 


\section{Resumo}

O estudo teve como objetivo avaliar o efeito da densidade de criação de 10,12, 14 e 16 aves $\mathrm{m}^{2}$ sobre o desempenho, os rendimentos de carcaça e cortes, a produtividade e o desenvolvimento ósseo de frangos de corte Cobb $500^{\circledR}$. O delineamento experimental foi inteiramente casualizado com quatro tratamentos (densidades de criação) e quatro repetições, as avaliações foram realizadas semanalmente aos: um, sete, 14, 21, 28, 35 e 42 dias. O melhor resultado de peso vivo foi encontrado na densidade de 10 aves $\mathrm{m}^{2}$ no período de 1-7 dias, não verificou efeito das densidades sobre consumo de ração e ganho de peso. De 1-14 dias os melhores pesos vivos foram encontrados na densidade de 10, 12 e 14 aves $\mathrm{m}^{2}$, o consumo de ração na densidade 10 e 12 aves $\mathrm{m}^{2}$ foi maior. $\mathrm{O}$ ganho de peso foi melhor na densidade de 10 aves $\mathrm{m}^{2}$, não diferindo das densidades de 12 e 14 aves $\mathrm{m}^{2}$. No período de 1-21 dias o peso vivo e ganho de peso foram maiores nas densidades de 10, 12 e 14 aves $\mathrm{m}^{2}$. O maior consumo de ração foi na densidade 10 aves $\mathrm{m}^{2}$, que não diferiu da densidade de 14 aves $\mathrm{m}^{2}$. Houve diferença $(\mathrm{P}<0,05)$ para peso vivo, ganho de peso e consumo de ração dos animais criados nas densidades de 10, 12 e 14 aves $\mathrm{m}^{2}$ para as fases de 1 a 35 dias e fase total de 1 a 42 dias de idade das aves, em comparação as de 16 aves $\mathrm{m}^{2}$ que apresentaram menores desempenhos. Porém, a conversão alimentar de 1-7, 1-14, 1-21, 1-35 e 1-42 dias e as características de carcaça e cortes não apresentaram diferenças significativas para nenhum tratamento. Já a produtividade foi maior nos tratamentos com 14 e 16 aves $\mathrm{m}^{2}$ não diferindo entre si. Não houve interação $(\mathrm{P}>0,05)$ entre densidade de criação e idade para nenhum parâmetro ósseo avaliado. Não houve diferença $(\mathrm{P}>0,05)$ no desenvolvimento ósseo dos frangos de corte criados nas diferentes densidades de criação para nenhum dos parâmetros estudados. Conclui-se que o aumento no número de aves por metro quadrado de 10 ou 12 aves $\mathrm{m}^{2}$, para 14 aves $\mathrm{m}^{2}$ não compromete o desempenho zootécnico, o rendimento de carcaça e cortes e não prejudica o desenvolvimento ósseo e ainda aumenta a produtividade de frangos de corte criados em galpão convencional sem climatização.

Palavras-chave: Cobb 500 ${ }^{\circledR}$. Fêmur. Peso vivo. Rendimento de peito. Tíbia.

\section{Introduction}

Brazil is the second largest producer and the world's largest exporter of chicken meat. In 2015, Brazil reached a chicken production of 13,146 million tons, behind only the United States, and managed to surpass China, which until 2014 was the second largest producer of chicken meat (ABPA, 2016).

Poultry farming is one of the most developed animal production sectors in recent years, especially in the chicken meat production sector. This is due to the rearing of a higher number of birds per $\mathrm{m}^{2}$, leading to a higher productivity. In addition, this development is also due to other factors such as breeding, responsible for the high precocity of the modern broiler chicken, and advances in nutrition, physiology, animal health, and management, which currently provide a 2.5-kilogram of live weight chicken when slaughtered at 42 days of age. These advances require adequate stocking conditions capable of tracking progress, allowing the bird to express its full genetic potential for production.

The growing pressure to reduce broiler chicken rearing costs, in addition to the high cost of food and the low prices paid for live chickens, has led companies and producers to increase stocking rate as a way to reduce labor costs and investments in new aviaries. In addition, chicken meat consumer market growth and its sophistication, as well as global competition, require a steady improvement in efficiency and productivity of industry sector (GOPINGER et al., 2015). Stocking density is another aspect to be considered in broiler chicken production since the excess of animals per area can cause stress and a consequent low performance, while area underutilization may affect the return on investments in facilities (ARAÚJO et al., 2007).

Moreira et al. (2004) assessed the stocking density effect $\left(10,13\right.$, and 16 birds $\left.\mathrm{m}^{-2}\right)$ on performance, carcass yield, and meat quality of 
three commercial strains of broiler chickens (Ross 308, Cobb 500, and Hybro PG). They concluded that an increased stocking density showed no effect on carcass yield and prime cuts (breast and legs), in addition to maintaining quality characteristics. These authors also observed a greater production of kilograms of live weight per $\mathrm{m}^{2}$ with the increased density, allowing increments in gross income.

Mortari et al. (2002) assessed the performance of broiler chickens reared at different stocking densities and observed that when increasing stocking density, revenue and profit are increased. The lowest economic return was obtained with 10 birds $\mathrm{m}^{-2}$ whereas the largest one was obtained with 16 birds $\mathrm{m}^{-2}$. This result was attributed to the good performance of birds reared at high stocking densities in relation to their food intake.

With a genetic selection focused on a high weight gain and high growth rates, large loads have been deposited on relatively immature bones and joints, leading to a poor bone formation and hence leg problems due to the lack of exercises (PONSO et al., 2012).

Oliveira et al. (2012), working with three genetic groups (Ross 308, Hybro PG, and Isa Label JA57) and two stocking densities (10 and 16 birds $\mathrm{m}^{-2}$ ), concluded that length, diameter, and weight of bones, in addition to Seedor index of long bones, had no influence from stocking densities, but increased with bird age.

Thus, the aim of this study was to assess the effect of stocking density of $10,12,14$, and 16 birds $\mathrm{m}^{-2}$ on performance, carcass and cut yields, productivity, and bone development of broiler chickens Cobb $500^{\circledR}$.

\section{Material and Methods}

The experiment was carried out from August 11 to September 22, 2015 at the experimental shed of broiler chickens of the Animal Science Sector of the Mato Grosso do Sul State University, Campus of
Cassilândia, MS, Brazil, located at the geographical coordinates $19^{\circ} 07^{\prime} 21^{\prime \prime} \mathrm{S}$ and $51^{\circ} 43^{\prime} 15^{\prime \prime}$, with an altitude of $516 \mathrm{~m}$.

The research project that originated this paper was conducted according to the technical standards of biosafety and ethics under the approval of the Ethics Committee on the Use of Animals (CEUA) of the Mato Grosso do Sul State University (UEMS), registered under the number $005 / 2014$ on page 7 of the book 1 .

A genetic group of broiler chickens of the strain Cobb $500^{\circledR}$, from a 60 -week-old broiler breeder hen, was obtained from the Pluma company at the Commercial Hatchery in Cassilândia for a total of 784 day-old chicks, mixed batch, being 392 males and 392 females with an average weight of 46.86 \pm 0.37 grams. The chicks were vaccinated in the hatchery against Gumboro, Marek, infectious bronchitis, and avian pox.

Ten more birds were added to each cage (replication) on the first day of the experiment because at 7, 14, 21, 28, 35, and 42 days two birds (one male and one female) were taken per repetition to perform bone analyses. This procedure was carried out aiming at maintaining, at 35 days of age, treatments with densities of 10,12,14, and 16 birds $\mathrm{m}^{-2}$. However, the number of birds housed in treatments per experimental unit (cages of $3 \mathrm{~m}^{2}$ ) were as follows: 40 birds for a density of 10 birds $\mathrm{m}^{-2}, 46$ birds for a density of 12 birds $\mathrm{m}^{-2}, 52$ birds for a density of 14 birds $\mathrm{m}^{-2}$, and 58 birds for a density of 16 birds $\mathrm{m}^{-2}$. Cages were placed in a conventional shed with fiber-cement tiles and dimensions of $22 \mathrm{~m}$ in length, $6 \mathrm{~m}$ in width, and $2.3 \mathrm{~m}$ of ceiling height. All the cages had dimensions of $3.0 \mathrm{~m}^{2}$ and were equipped with a heating source with lamps of $110 \mathrm{v}$ of $150 \mathrm{~W}$. A wood shaving litter of approximately 8 $\mathrm{cm}$ of height was used on the floor.

During the first 10 days of the chick's life, pressure cup-type drinking fountains and tubular feeders for chicks were used, being later gradually replaced by automatic bell-drinking fountains and 
tubular feeders for adult animals. In each cage, a protection circle of wooden frames at a height of 60 $\mathrm{cm}$ was used to protect the chicks during the first days of life, keeping them near the heating source, feeder, and drinking fountain, in addition to avoiding drafts. These circles were opened as the chicks grew and needed more space. On the eleventh day, the protection cycles were removed for a greater bird comfort.

A continuous light program was adopted during the 42 days of bird age. The internal temperature was recorded with a maximum and minimum digital thermometer maintained at the shed's center, being monitored twice a day (at 7:30 and 16:00 h) during the experimental period. The minimum and maximum average temperatures were, respectively, 19.8 and $35.1^{\circ} \mathrm{C}$ at the phase of $1-21$ days, 22.6 and $32.7{ }^{\circ} \mathrm{C}$ at the phase of $22-35$ days, and 22.7 and $38.5{ }^{\circ} \mathrm{C}$ at the phase of $36-42$ days. The minimum and maximum average temperatures during the experimental period (1-42 days) were 21.3 and 34.8 ${ }^{\circ} \mathrm{C}$, respectively.

Corn- and soybean meal-based diets were used to feed the birds, being adapted from dietary reference intake tables of broiler chicken by Rostagno (2011). A three-phase program was used, i.e. an initial (1 to 21 days), growth (22 to 35 days), and final (36 to 42 days) feed, whose compositions are presented in Table 1. Feed and water were supplied ad libitum for birds throughout the experimental period.

Table 1. Centesimal and chemical composition of experimental diets of broiler chickens at the initial (1-21 days), growth (22-35 days), and final (36-42 days) phases.

\begin{tabular}{lccc}
\hline Ingredient (\%) & $\begin{array}{c}\text { Initial phase } \\
(1-21 \text { days })\end{array}$ & $\begin{array}{c}\text { Growth phase } \\
(22-35 \text { days })\end{array}$ & $\begin{array}{c}\text { Final phase } \\
(36-42 \text { days })\end{array}$ \\
\hline Ground corn & 53.23 & 54.54 & 62.00 \\
Soybean meal & 39.94 & 37.53 & 30.49 \\
Soybean oil & 2.91 & 4.71 & 4.70 \\
Dicalcium phosphate & 1.61 & 1.10 & 0.90 \\
Calcitic limestone & 1.40 & 1.43 & 1.33 \\
Salt & 0.45 & 0.33 & 0.25 \\
Mineral-vitamin supplement ${ }^{1}$ & 0.15 & 0.20 & 0.20 \\
DL-Methionine & 0.21 & 0.06 & 0.03 \\
BHT & 0.10 & 0.10 & 0.10 \\
\hline Total & 100.00 & 100.00 & 100.00 \\
\hline Calculated nutritional values & & & 3,200 \\
\hline Metabolizable energy (ME) (kcal kg $\left.{ }^{-1}\right)$ & 2,950 & 3,100 & 18.50 \\
Crude protein (CP) (\%) & 22.00 & 21.00 & 0.80 \\
Calcium (\%) & 1.00 & 0.90 & 0.30 \\
Available phosphorus (\%) & 0.45 & 0.35 & 0.60 \\
Total methionine + cystine (\%) & 0.90 & 0.72 & 0.32 \\
Methionine (\%) & 0.53 & 0.38 & 0.85 \\
Lysine (\%) & 1.24 & 1.00 & 172.97 \\
ME to CP ratio & 134.10 & 147.62 & \\
\hline
\end{tabular}

${ }^{1}$ Vitamin-premix Multi Frango and Multi Mix and mineral-premix Multi Mix., Nucleopar S.A. Nutritional levels per kg of premix: vitamin A, 8,000,000 IU; vitamin D3, 2,200,000 IU; vitamin E, 6200 mg; vitamin K3, 2000 mg; vitamin B1, 2000 mg; vitamin B2, $3000 \mathrm{mg}$; vitamin B6, $6000 \mathrm{mg}$; vitamin B12, 10,000 mcg; calcium pantothenate, $6000 \mathrm{mg}$; Niacin, 25,000 mg; folic acid, $400 \mathrm{mg}$; Se, 100 mg; Mn, 65,000 mg; Fe, 40,000 mg; Cu, 10,000 mg; Zn, 50,000 mg; I, 1000 mg Zn, 50,000 mg. 


\section{Analyzed variables}

Broiler chicken performance was assessed by live weight (at 7, 14, 21, 35, and 42 days), weight gain, feed intake, and feed conversion (1-7, 1-14, 1-21, 1-35, and 1-42 days). For this, diets and birds were weighed at the beginning of the experiment (day 1), $7,14,21,28,35$, and 42 days. Feed conversion was corrected for mortality according to Sakomura and Rostagno (2007).

At 42 days of age, two birds with $\pm 5 \%$ of the average weight of the birds in the cage were chosen, one male and another female per experimental unit, totaling eight birds per treatment, for the assessment of carcass and cut characteristics and, subsequently, bone characteristics. After 8 hours of food fasting, birds were desensitized by electronarcosis $(220 \mathrm{~V})$, followed by bleeding, scalding in boiling water, plucking, evisceration, and weighing the eviscerated carcass (without feet, head, and viscera) to calculate carcass yield in relation to animal live weight. Subsequently, legs (thigh and drumstick) and breast were cut, being weighed to calculate leg and breast yields in relation to carcass weight. Productivity was calculated using the following formula: $\mathrm{kg}$ of live weight $\mathrm{m}^{-2}=$ number of birds $\times$ average weight of birds at 42 days of age / 3 , where 3 is the size of each cage $\left(3 \mathrm{~m}^{2}\right)$.

Two birds (average weight of the birds in the cage) per repetition were sacrificed weekly at 7,14 , $21,28,35$, and 42 days of age for the assessment of bone development by collecting the long bones (tibia and femur). For a better standardization, the right-side bones were collected and frozen. At the time of carrying out the analyses, bones were placed in boiling water for approximately 10 seconds before being stripped to perform bone analyses.

For the measurements of bone weight, a precision analytical balance $( \pm 0.0001 \mathrm{~g})$ was used. Both bone length and thickness were measured using a digital caliper $(0.1 \mathrm{~mm})$. The bone length was measured taking the greatest distance between the epiphyses whereas bone thickness was measured by taking the central bone point. All measurements were always carried out at the same points in all bones. The Seedor index (SEEDOR et al., 1991) was calculated from both bone weight and length (bone weight, expressed in mg, divided by bone length, expressed in $\mathrm{mm}$ ). This index is an indication of bone density, i.e. the higher the Seedor index is, the higher the bone density, and vice versa.

\section{Experimental design and statistical analysis}

The experimental design was a completely randomized design with four treatments, represented by stocking densities of 10, 12, 14, and 16 birds $\mathrm{m}^{-2}$, with four replications each, totaling 16 experimental units. For the analysis of bone parameters, treatments were the stocking densities and subplots were the ages of the bone collection.

The data of performance, carcass and cut yields, and productivity were submitted to analysis of variance and the means were compared by the Tukey's test at 5\% probability level. The data related to bone development were previously tested for normality by the Kolmogorov-Smirnov test. If unmet, the data were transformed by means of Box-Cox transformation family, given by the equation: $\mathrm{y} \lambda=\left(\mathrm{y}^{\lambda}-1\right) / \lambda$. Subsequently, in order to analyze the differences between treatments of stocking density of broiler chickens, an analysis of variance (ANOVA) was performed and the means compared by the Tukey's test at 5\% probability level. All statistical analyses were performed using the software Sisvar (FERREIRA, 2011).

\section{Results and Discussion}

No effect of densities $(\mathrm{P}>0.05)$ on feed intake, weight gain, and feed conversion was observed in the period of 1-7 days since the birds were smaller at this early phase and had enough space for moving toward feeders and drinking fountains, disregarding the stocking density (Table 2). Birds housed at a density of 10 birds $\mathrm{m}^{-2}$ obtained the highest live 
weight whereas birds reared at densities of 12 and 14 birds $\mathrm{m}^{-2}$ presented lower weights, without differing from those housed at a density of 10 birds $\mathrm{m}^{-2}$. On the other hand, the lowest live weight was found at a density of 16 birds $\mathrm{m}^{-2}$.

Table 2. Average live weight (LW), weight gain (WG), feed intake (FI), and feed conversion (FC) in broiler chickens reared at different stocking densities in the period of 1-7, 1-14, 1-21, 1-35, and 1-42 days of age.

\begin{tabular}{|c|c|c|c|c|c|c|}
\hline \multicolumn{7}{|c|}{ Stocking density (birds $\mathrm{m}^{-2}$ ) } \\
\hline \multirow[t]{2}{*}{ Parameter } & 10 & 12 & 14 & 16 & $\mathrm{P}<0.05$ & $* \mathrm{CV}(\%)$ \\
\hline & \multicolumn{6}{|c|}{ Period of 1-7 days } \\
\hline LW at 7 days $(\mathrm{g})$ & $196 a$ & $191 \mathrm{ab}$ & $191 \mathrm{ab}$ & $189 \mathrm{~b}$ & 0.0565 & 1.81 \\
\hline $\mathrm{FI}(\mathrm{g})$ & 169 & 167 & 162 & 162 & 0.3946 & 4.34 \\
\hline WG (g) & 149 & 143 & 144 & 142 & 0.0794 & 2.52 \\
\hline \multirow[t]{2}{*}{$\mathrm{FC}$} & 1.136 & 1.167 & 1.124 & 1.142 & 0.6983 & 4.49 \\
\hline & \multicolumn{6}{|c|}{ Period of 1-14 days } \\
\hline LW at 14 days (g) & $489 \mathrm{a}$ & $476 \mathrm{ab}$ & $474 \mathrm{ab}$ & $454 b$ & 0.0242 & 2.83 \\
\hline $\mathrm{FI}(\mathrm{g})$ & $648 \mathrm{a}$ & $594 \mathrm{ab}$ & $587 \mathrm{~b}$ & $574 b$ & 0.0094 & 4.44 \\
\hline WG (g) & $441 \mathrm{a}$ & $428 \mathrm{ab}$ & $427 \mathrm{ab}$ & $407 \mathrm{~b}$ & 0.0281 & 3.17 \\
\hline \multirow[t]{2}{*}{$\mathrm{FC}$} & 1.468 & 1.387 & 1.372 & 1.417 & 0.5664 & 7.11 \\
\hline & \multicolumn{6}{|c|}{ Period of 1-21 days } \\
\hline LW at 21 days $(\mathrm{g})$ & $969 a$ & $955 \mathrm{a}$ & $951 \mathrm{ab}$ & $900 \mathrm{~b}$ & 0.0100 & 2.58 \\
\hline $\mathrm{FI}(\mathrm{g})$ & $1595 \mathrm{a}$ & $1385 b$ & $1511 \mathrm{ab}$ & $1340 \mathrm{~b}$ & 0.0085 & 6.39 \\
\hline WG $(g)$ & $921 \mathrm{a}$ & $908 \mathrm{a}$ & $904 \mathrm{ab}$ & $854 b$ & 0.0109 & 2.73 \\
\hline \multirow[t]{2}{*}{$\mathrm{FC}$} & 1.731 & 1.527 & 1.673 & 1.573 & 0.1254 & 7.49 \\
\hline & \multicolumn{6}{|c|}{ Period of $1-35$ days } \\
\hline LW at 35 days (g) & $2154 a$ & $2097 \mathrm{a}$ & $2065 \mathrm{a}$ & $1931 b$ & 0.0002 & 2.35 \\
\hline $\mathrm{FI}(\mathrm{g})$ & $3654 a$ & $3429 a$ & $3523 a$ & $3183 b$ & 0.0008 & 3.41 \\
\hline WG (g) & $2107 \mathrm{a}$ & $2049 a$ & $2018 \mathrm{a}$ & $1885 b$ & 0.0002 & 2.42 \\
\hline \multirow[t]{2}{*}{$\mathrm{FC}$} & 1.734 & 1.674 & 1.746 & 1.689 & 0.2217 & 3.08 \\
\hline & \multicolumn{6}{|c|}{ Period of 1-42 days } \\
\hline LW at 42 days (g) & $2617 \mathrm{a}$ & $2605 a$ & $2547 \mathrm{a}$ & $2350 \mathrm{~b}$ & 0.0002 & 2.50 \\
\hline FI (g) & $4802 \mathrm{a}$ & $4641 \mathrm{a}$ & $4638 \mathrm{a}$ & $4194 b$ & 0.0008 & 3.40 \\
\hline WG $(g)$ & $2570 \mathrm{a}$ & $2557 \mathrm{a}$ & $2499 a$ & $2304 b$ & 0.0002 & 2.56 \\
\hline $\mathrm{FC}$ & 1.869 & 1.815 & 1.855 & 1.821 & 0.6025 & 3.61 \\
\hline
\end{tabular}

Means followed by different letters in the same line, for each variable, differ from each other by the Tukey's test at $5 \%$ probability $(\mathrm{P}<0.05)$. ${ }^{*}$ Coefficient of variation.

Considering bird rearing in the period of 1-14 days (Table 2), live weight and weight gain of birds decreased as stocking density increased. Thus, the stocking density of 10 birds $\mathrm{m}^{-2}$ presented the best live weight and weight gain, densities of 12 and 14 birds $\mathrm{m}^{-2}$ were statistically equal, and the density of
16 birds $\mathrm{m}^{-2}$ presented the lowest live weight and weight gain. For feed intake, birds reared at a density of 10 birds $\mathrm{m}^{-2}$ had a higher consumption as those reared at a density of 12 birds $\mathrm{m}^{-2}$. However, birds reared at densities of 14 and 16 birds $\mathrm{m}^{-2}$ presented a lower feed intake with no variations from each 
other. No difference $(\mathrm{P}>0.05)$ was observed for feed conversion at the assessed densities.

Table 2 shows that in the period of 1-21 days, live weight and weight gain of birds were higher $(\mathrm{P}<0.05)$ at densities of 10,12 , and 14 birds $\mathrm{m}^{-2}$, being similar for treatments with 14 and 16 birds $\mathrm{m}^{-2}$, in which birds had a lower live weight and weight gain. The highest feed intake $(\mathrm{P}<0.05)$ was observed for birds at densities of 10 and 14 birds $\mathrm{m}^{-2}$ whereas feed conversion had no influence from the assessed densities $(\mathrm{P}>0.05)$.

Considering the periods of 1-35 and 1-42 days of bird age (Table 2), the best results $(\mathrm{P}<0.05)$ of live weight, weight gain, and higher feed intake were observed for birds reared at densities of 10, 12, and 14 birds $\mathrm{m}^{-2}$. This is due to the lower number of birds in the cages, providing a better comfort, greater physical space, and easy access to feeders and drinking fountains. Birds housed at a density of 16 birds $\mathrm{m}^{-2}$ presented a lower live weight and weight gain due to the greater number of birds per $\mathrm{m}^{2}$, hindering the movement and free access to feeders and drinking fountains. Furthermore, this high density led to a less comfort due to bird agglomeration, increasing local temperature and reducing bird performance mainly due to a lower feed intake.

A decreased access to feeders led to a lower feed intake $(\mathrm{P}<0.05)$ for birds housed at the highest stocking density ( 16 birds $\mathrm{m}^{-2}$ ), thus causing a lower bird performance when compared to those housed at lower densities (10 to 14 birds $\mathrm{m}^{-2}$ ). However, no effect of densities $(\mathrm{P}>0.05)$ on feed conversion was observed for the assessed periods.

The data obtained in this study are in accordance with those found by Oliveira et al. (2005), who assessed the performance of broiler chickens reared at two stocking densities (10 and 14 birds $\mathrm{m}^{-2}$ ) and different litter types and observed that feed intake decreased as stocking density increased. At a density of 10 birds $\mathrm{m}^{-2}$, birds had a higher feed intake. These results are also in accordance with those found by Lana et al. (2001), who studied stocking densities of 10,12 , and 16 birds $\mathrm{m}^{-2}$ and two feeding programs composed of different feed types. These authors observed that at a density of 10 birds $\mathrm{m}^{-2}$, feed intake was higher regardless of the feeding program. These results confirm that the higher the density is, the lower the feed intake and, consequently, the lower the live weight and weight gain of animals.

The data on weight gain, feed intake, and feed conversion in the total rearing period (Table 2) are within the productive parameters for mixed lots according to Cobb-Vandress (2013). Thus, birds reared at a density of 14 birds $\mathrm{m}^{-2}$ expressed their best productive potential $(\mathrm{P}<0.05)$ when compared to birds reared at the highest density $\left(16\right.$ birds $\left.\mathrm{m}^{-2}\right)$. Mortari et al. (2002), studying the performance of broiler chickens reared at densities of $10,12,14$, and 16 birds $\mathrm{m}^{-2}$, observed a decreased weight gain as the density increased. These authors concluded that feed intake and live weight were higher in birds reared at lower densities, but feed conversion and rearing viability showed no effect from stocking density, which was also observed in this study.

In a study conducted by Moreira et al. (2004), the increase in density of 10 birds $\mathrm{m}^{-2}$ led to a reduction in weight gain, especially at the final rearing phase. However, at an intermediate density of 13 birds $\mathrm{m}^{-2}$, weight gain was similar to that obtained with a density of 16 birds $\mathrm{m}^{-2}$.

When working with two fast-growing strains (Hybro PG and Ross), Oliveira et al. (2012) observed a lower performance for birds reared at a high density (16 birds $\mathrm{m}^{-2}$ ), showing that physical space influenced bird performance. Goldflus et al. (1997) also found similar results when working with densities of $10,14,18$, and 22 birds $\mathrm{m}^{-2}$. These authors observed a gradual reduction in feed intake as the space available was reduced, resulting in a linear decrease of weight gain, with a consequent weight gain decrease during the total rearing period. Stocking density is even more important 
for high-performance strains, which have different management and nutrition requirements (PILECCO et al., 2011).

The absence of density effect on feed conversion corroborates the results found by Mortari et al. (2002), who showed no difference in feed conversion between densities of 10, 12, 14, and 16 birds $\mathrm{m}^{-2}$. On the contrary, Albuquerque et al. (2006), who worked with densities of 10 and 15 birds $\mathrm{m}^{-2}$, observed that feed conversion was better at the lowest stocking rate in the periods of 1-21 and 22-45 days of age.

One of the main factors influencing animal performance is the ambient temperature. In the total rearing period (1-42 days), a maximum average of $34.8^{\circ} \mathrm{C}$ was obtained. Because the birds were reared in a conventional shed without air conditioning and during a period of high temperatures, the ambient temperature was far above the thermal comfort zone of birds, affecting the productive performance mainly when housed at the highest densities (14 and 16 birds $\mathrm{m}^{-2}$ ). Therefore, the results of this study show a decreased feed intake, especially for birds housed at stocking densities of 14 and 16 birds $\mathrm{m}^{-2}$, leading to a lower weight gain and live weight since the birds needed to use part of the energy ingested to maintain body temperature. For this reason, feed conversion was higher (with an average between the densities of 1.840) than that recommended for the strain during the total rearing period.

Carcass weight data were higher $(\mathrm{P}<0.05)$ for birds reared at densities of 10,12 , and 14 birds $\mathrm{m}^{-2}$ (Table 3 ). The data of eviscerated carcass yield, total leg yield, and breast yield had no effect $(\mathrm{P}>0.05)$ from the different stocking densities used (Table 3). No differences were observed since a small carcass has a smaller cut whereas a large carcass has a large cut, with the same percentage. These data are in accordance with those found by Mortari et al. (2002), who assessed broiler chicken performance at four stocking densities $(10,12,14$, and 16 birds $\mathrm{m}^{-2}$ ) and observed those densities affected carcass characteristics.

Table 3. Averages of carcass weight, eviscerated carcass yield (ECY), leg yield (Yleg), breast yield (Ybreast), and productivity in broiler chickens reared at different stocking densities at 42 days of age.

\begin{tabular}{lcccccc}
\hline Parameter & $1^{10}$ birds m$^{-2}$ & 12 birds m$^{-2}$ & 14 birds m $^{-2}$ & 16 birds m$^{-2}$ & $\mathrm{P}<0.05$ & ${ }^{*} \mathrm{CV}(\%)$ \\
\hline Carcass weight & $1944 \mathrm{a}$ & $1872 \mathrm{ab}$ & $1863 \mathrm{ab}$ & $1742 \mathrm{~b}$ & 0.0629 & 5.06 \\
ECY (\%) & 74.07 & 74.07 & 74.56 & 73.53 & 0.4690 & 1.20 \\
Yleg (\%) & 27.77 & 27.15 & 26.96 & 27.47 & 0.6844 & 3.69 \\
Ybreast (\%) & 37.07 & 37.72 & 37.36 & 37.79 & 0.8969 & 4.03 \\
Productivity (kg live weight $\mathrm{m}^{-2}$ ) & $29.90 \mathrm{c}$ & $36.02 \mathrm{~b}$ & $42.74 \mathrm{a}$ & $43.41 \mathrm{a}$ & 0.0000 & 4.92 \\
\hline
\end{tabular}

Means followed by different letters in the same line, for each variable, differ from each other by the Tukey's test at $5 \%$ probability $(\mathrm{P}<0.05)$. ${ }^{*}$ Coefficient of variation.

Carcass yield results were excellent, as shown in Table 3. Considering that in the experimental period from 36 to 42 days the minimum and maximum temperatures were 22.7 and $38.5{ }^{\circ} \mathrm{C}$, respectively, with an average temperature of $30.6{ }^{\circ} \mathrm{C}$, and that the ideal temperature for birds is $18^{\circ} \mathrm{C}$ at this phase (COBB-VANDRESS, 2009), animals presented an excellent breast yield (average of 37.49\%). Polcaro-Silva (2013) found similar results for breast yield in chicken Cobb $500^{\circledR}$ when assessing three commercial chicken strains (Cobb 500 ${ }^{\circledR}$, Hubbard Flex, and Ross 308), with a value of breast yield of $36.72 \%$ at 42 days. Santos et al. (2005), studying growth, performance, carcass yield, and meat quality in three broiler chicken strains, found a breast yield of $34.35 \%$ with the strain Cobb $500^{\circledR}$.

Chicken productivity at 42 days of age was influenced $(\mathrm{P}<0.05)$ by different stocking densities 
(Table 3). The density of 10 birds $\mathrm{m}^{-2}$ presented the lowest productivity $\left(29.90 \mathrm{~kg}\right.$ live weight $\left.\mathrm{m}^{-2}\right)$ since this treatment had fewer birds whereas the density of 12 birds $\mathrm{m}^{-2}$ presented a productivity of $36.02 \mathrm{~kg}$ live weight $\mathrm{m}^{-2}$. The best averages of productivity were observed at densities of 14 (42.74 $\mathrm{kg}$ live weight $\mathrm{m}^{-2}$ ) and 16 birds $\mathrm{m}^{-2}$ (43.41 $\mathrm{kg}$ live weight $\mathrm{m}^{-2}$ ), with no difference from each other although the density of 14 birds $\mathrm{m}^{-2}$ have had a lower number of birds when compared to the density of 16 birds $\mathrm{m}^{-2}$. This is due to the weight of animals reared at the density of 14 birds $\mathrm{m}^{-2}$ be higher throughout the experimental period when compared to birds reared at the highest density. These data are in accordance with the results found by Moreira et al. (2004), who assessed the effect of stocking density on performance, carcass yield, and meat quality in broiler chickens of different commercial strains and concluded that the amount of meat per $\mathrm{m}^{2}$ increases as stocking density increases.

No interaction $(\mathrm{P}>0.05)$ was observed between stocking density and length, diameter, weight, and Seedor index of tibia and femur (Tables 4, 5, 6, and 7). In addition, no difference ( $\mathrm{P}>0.05$ ) was observed between bone development in broiler chickens reared at different stocking densities and the studied parameters (Tables 4, 5, 6, and 7).

All parameters related to bone development (length, diameter, weight, and Seedor index) increased $(\mathrm{P}<0.05)$ with bird age $(7,14,21,28,35$, and 42 days). These results were expected since growth and bone density (Seedor index) remained always increasing over the days because birds were at growth phase, corroborating the results found by Oliveira et al. (2012), who observed that these parameters increased with bird age over the rearing period.

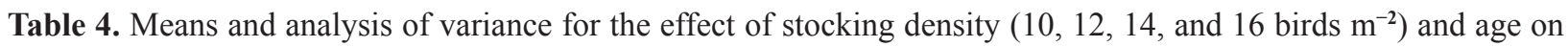
the length of long bones (tibia and femur) in broiler chickens.

\begin{tabular}{lcc}
\hline Stocking density $\left(\right.$ birds $\left.^{-2}\right)$ & Tibia length $(\mathrm{mm})$ & Femur length $(\mathrm{mm})$ \\
\hline 10 & 75.61 & 58.86 \\
12 & 75.39 & 58.36 \\
14 & 75.29 & 58.05 \\
16 & 74.23 & 57.65 \\
\hline Age (days) & & \\
\hline 7 & $42.99 \mathrm{~F}$ & $33.17 \mathrm{~F}$ \\
14 & $56.37 \mathrm{E}$ & $44.20 \mathrm{E}$ \\
21 & $70.76 \mathrm{D}$ & $55.96 \mathrm{D}$ \\
28 & $84.03 \mathrm{C}$ & $65.48 \mathrm{C}$ \\
35 & $93.70 \mathrm{~B}$ & $71.94 \mathrm{~B}$ \\
42 & $102.92 \mathrm{~A}$ & $78.63 \mathrm{~A}$ \\
\hline$*$ CV $(\%)$ & 2.42 & 3.01 \\
\hline Source of variation & & \\
\hline Density & 0.0506 & 0.1334 \\
Age & 0.0000 & 0.0000 \\
Density $\times$ Age & 0.6714 & 0.9629 \\
\hline
\end{tabular}

Means followed by different letters in the same column, for each variable, differ from each other by the Tukey's test at $5 \%$ probability $(\mathrm{P}<0.05)$. *Coefficient of variation.

According to Muniz et al. (2007), the nutritional view of locomotor problems in broiler chickens disregard the bones as exclusively mechanical support tissues, but heterogeneous and complex tissues, which support animal musculature and weight, in addition to being related to growth 
in its multiple functions in an organized and precisely controlled manner. The authors, assessing calcium sources for broiler chickens, observed that carbochelate provided a lower diameter and length of the tibia when compared to other calcium sources, showing that the differences in calcium availability of sources used in diets may interfere with the bone growth of birds at the initial phase.

Table 5. Means and analysis of variance for the effect of stocking density (10, 12, 14 and 16 birds $\left.\mathrm{m}^{-2}\right)$ and age on the diameter of long bones (tibia and femur) in broiler chickens.

\begin{tabular}{lcc}
\hline Stocking density $\left(\right.$ birds $\left.^{-2}\right)$ & Tibia diameter $(\mathrm{mm})$ & Femur diameter $(\mathrm{mm})$ \\
\hline 10 & 6.19 & 6.66 \\
12 & 6.18 & 6.72 \\
14 & 6.18 & 6.55 \\
16 & 5.95 & 6.53 \\
\hline Age (days) & & \\
\hline 7 & $2.81 \mathrm{~F}$ & $3.05 \mathrm{~F}$ \\
14 & $4.43 \mathrm{E}$ & $5.03 \mathrm{E}$ \\
21 & $6.05 \mathrm{D}$ & $6.51 \mathrm{D}$ \\
28 & $7.09 \mathrm{C}$ & $7.59 \mathrm{C}$ \\
35 & $7.98 \mathrm{~B}$ & $8.36 \mathrm{~B}$ \\
42 & $8.39 \mathrm{~A}$ & $9.16 \mathrm{~A}$ \\
\hline$* \mathrm{CV}(\%)$ & 10.35 & 8.62 \\
\hline Source of variation & Probability $>\mathrm{F}$ & \\
\hline Density & 0.1814 & 0.2082 \\
Age & 0.0000 & 0.0000 \\
Density $\times$ Age & 0.9781 & 0.9649 \\
\hline
\end{tabular}

Means followed by different letters in the same column, for each variable, differ from each other by the Tukey's test at $5 \%$ probability $(\mathrm{P}<0.05)$. *Coefficient of variation.

Table 6. Means and analysis of variance for the effect of stocking density $\left(10,12,14\right.$, and 16 birds $\left.\mathrm{m}^{-2}\right)$ and age on the weight of long bones (tibia and femur) in broiler chickens.

\begin{tabular}{lcc}
\hline Stocking density $\left(\right.$ birds $\left.^{-2}\right)$ & Tibia weight $(\mathrm{mg})$ & Femur weight $(\mathrm{mg})$ \\
\hline 10 & 8.18 & 7.24 \\
12 & 8.20 & 7.18 \\
14 & 8.17 & 7.19 \\
16 & 7.81 & 6.90 \\
\hline Age (days) & & \\
\hline 7 & $1.26 \mathrm{~F}$ & $1.08 \mathrm{~F}$ \\
14 & $3.09 \mathrm{E}$ & $2.79 \mathrm{E}$ \\
21 & $6.23 \mathrm{D}$ & $5.49 \mathrm{D}$ \\
28 & $9.79 \mathrm{C}$ & $8.72 \mathrm{C}$ \\
35 & $12.58 \mathrm{~B}$ & $10.94 \mathrm{~B}$ \\
42 & $15.57 \mathrm{~A}$ & $13.74 \mathrm{~A}$ \\
\hline$*$ CV $(\%)$ & 5.64 & 6.32 \\
\hline Source of variation & Probability $>\mathrm{F}$ & \\
\hline Density & 0.1023 & 0.1375 \\
Age & 0.0000 & 0.0000 \\
Density $\times$ Age & 0.9887 & 0.9888 \\
\hline
\end{tabular}

Means followed by different letters in the same column, for each variable, differ from each other by the Tukey's test at $5 \%$ probability $(\mathrm{P}<0.05)$. ${ }^{*}$ Coefficient of variation. 


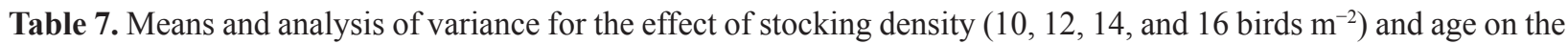
Seedor index of long bones (tibia and femur) in broiler chickens.

\begin{tabular}{|c|c|c|}
\hline Stocking density (birds $\mathrm{m}^{-2}$ ) & Seedor index of tibia $\left(\mathrm{mg} \mathrm{mm}^{-1}\right)$ & Seedor index of femur $\left(\mathrm{mg} \mathrm{mm}^{-1}\right)$ \\
\hline 10 & 0.10 & 0.11 \\
\hline 12 & 0.10 & 0.11 \\
\hline 14 & 0.10 & 0.11 \\
\hline 16 & 0.09 & 0.11 \\
\hline \multicolumn{3}{|l|}{ Age (days) } \\
\hline 7 & $0.03 \mathrm{~F}$ & $0.03 \mathrm{~F}$ \\
\hline 14 & $0.05 \mathrm{E}$ & $0.07 \mathrm{E}$ \\
\hline 21 & $0.09 \mathrm{D}$ & $0.10 \mathrm{D}$ \\
\hline 28 & $0.12 \mathrm{C}$ & $0.13 \mathrm{C}$ \\
\hline 35 & $0.13 \mathrm{~B}$ & $0.16 \mathrm{~B}$ \\
\hline 42 & $0.15 \mathrm{~A}$ & $0.17 \mathrm{~A}$ \\
\hline$* \mathrm{CV}(\%)$ & 0.58 & 0.73 \\
\hline Source of variation & Probability $>$ F & \\
\hline Density & 0.4134 & 0.2809 \\
\hline Age & 0.0000 & 0.0000 \\
\hline Density $\times$ Age & 0.9422 & 0.9858 \\
\hline
\end{tabular}

Means followed by different letters in the same column, for each variable, differ from each other by the Tukey's test at $5 \%$ probability $(\mathrm{P}<0.05)$. *Coefficient of variation.

Bruno et al. (2007) analyzed the influence of qualitative food restriction and ambient temperature on the development of long bones using a density of 12 birds $\mathrm{m}^{-2}$. These authors observed that tibia and femur lengths had no influence from food program, but femur diameter $(6.90 \pm 0.24 \mathrm{~mm})$ was affected in the Ross strain, which also presents a fast growth. The results found by these authors differed from those found in this study, in which femur diameter was $6.72 \pm 0.071 \mathrm{~mm}$, also at a density of 12 birds $\mathrm{m}^{-2}$, but length and diameter showed no differences from the other stocking densities in this experiment $\left(7,14\right.$, and 16 birds $\left.\mathrm{m}^{-2}\right)$. In addition, these authors obtained lower values of length and diameter of tibia and femur over the weeks when compared with the same ages analyzed in this study $(14,21,28,35$, and 42 days of age) considering the values obtained at a density of 12 birds $\mathrm{m}^{-2}$.

Live weight and Seedor index presented no effect of the stocking densities $(\mathrm{P}>0.05)$, but age determined the differences $(\mathrm{P}<0.05)$ (Table 6 and 7 , respectively). Bone length increases over the days, leading to an increase in weight and hence in Seedor index since the bone gets denser over the days.

Oliveira et al. (2012) assessed bone development of three genetic groups (Ross 308, Hybro PG, and Isa Label JA57) and two stocking densities (10 and 16 birds $\mathrm{m}^{-2}$ ) and concluded that the different genetic groups affected the physical parameters related to bone (length, diameter, weight, and Seedor index) for both stocking densities.

\section{Conclusion}

Therefore, the increased density of 10 or 12 birds $\mathrm{m}^{-2}$ to 14 birds $\mathrm{m}^{-2}$ had no effect on zootechnical performance, carcass and cut yields, and bone development, but increases broiler chicken productivity reared in a conventional shed without air conditioning.

\section{Acknowledgements}

To the Fundect, for granting the scholarship. 


\section{References}

ALBUQUERQUE, R.; MARCHETTI, L. K.; FAGUNDES, C.A.; BITTENCOURT, L. C.; TRINDADE NETO, M. A.; LIMA, F. R. Efeito de diferentes densidades populacionais e do sexo sobre o desempenho e uniformidade em frangos de corte. Brazilian Journal Veterinary Researchand Animal Science, Pirassununga, v. 43, n. 5, p. 581-587, 2006.

ARAÚJO, J. S.; OliveirA, V.; BRAGA, G. C. Desempenho de frangos de corte criados em diferentes tipos de cama e taxa de lotação. Ciência Animal Brasileira, Chapadinha, v. 8, n. 1, p. 59-64, 2007.

ASSOCIAÇÃO BRASILEIRA DE PROTEÍNA ANIMAL - ABPA. História da avicultura no Brasil. São Paulo: ABPA, 2016. Disponível em: $<$ http://www.ubabef. com.br/a_avicultura_brasileira/historia_da_avicultura no_brasil $\geq$. Acesso em: 3 mar. 2016.

BRUNO, L. D. G.; LUQUETTI, B. C.; FURLAN, R. C.; MACARI, C. M. Influence of early qualitative feed restriction and environmental temperature on long bone development of broiler chicken. Journal of Thermal Biology, v. 32, n. 6, p. 349-354, 2007.

COBB-VANDRESS.COM. Manual de manejo de frangos de corte. Guapiaçu: [s.n]. 2009. Disponível em: <http:// wp.ufpel.edu.br/avicultura/files/2012/04/Cobb-ManualFrango-Corte-BR.pdf>. Acesso em: 18 jan. 2016.

Suplemento: desempenho e nutrição para $\overline{\text { frangos }}$ de corte. Guapiaçu: [s.n]. 2013. Disponível em: <http://www.cobb-vantress.com/languages/ guidefiles/793a16cc-5812-4030-9436-1e5da177064f_ pt.pdf $>$. Acesso em: 25 maio 2016.

FERREIRA, D. F. Sisvar: a computer statistical analysis system. Ciência e Agrotecnologia, Lavras, v. 35, n. 6, p. 1039-1042, 2011.

GOLDFLUS, F.; ARIKI, F.; KRONKA, S. N.; SAKOMURA, N. K.; BARBOSA, V. M. M. Efeitos de diferentes densidades populacionais nas estações fria e quente do ano sobre o desempenho de frangos de corte. Revista Brasileira de Zootecnia, Viçosa, MG, v. 26, n. 5, p. 948-954, 1997.

GOPINGER, E.; XAVIER, E. G.; SILVA, S. N. S.; ROLL, V. F. B. Farelo de canola e seu uso na nutrição de frangos de corte: revisão. Revista Portuguesa de Ciências Veterinárias, Capão do Leão, v. 110, n. 593594, p. 17-22, 2015.

LANA, G. R. Q.; SILVA JUNIOR, R. G. C.; VALERIO, S. R.; LANA, A. M. Q.; BASTO, E. C. G. Efeito da densidade e de programas de alimentação sobre o desempenho de frangos de corte. Revista Brasileira de
Zootecnia, Viçosa, MG, v. 30, n. 4, p. 1258-1258, 2001.

MOREIRA, J.; MENDES, A. A.; ROÇA, R. O.; GARCIA, E. A.; NAAS, I. A.; GARCIA, R. G.; PAZ, I. C. L. A. Efeito da densidade populacional sobre desempenho, rendimento de carcaça e qualidade da carne em frangos de corte de diferentes linhagens comerciais. Revista Brasileira de Zootecnia, Viçosa, MG, v. 33, n. 6, p. 1506-1519, 2004.

MORTARI, A. C.; ROSA, A. P.; ZANELLA, I.; BERETTA NETO, C.; VISENTINI, P. R.; BRITES, L. B. P. Desempenho de frangos de corte criados em diferentes densidades populacionais, no inverno no Sul do Brasil. Ciências Rural, Santa Maria, v. 32, n. 3, p. 493-497, 2002.

MUNIZ, E. B.; ARRUDA, A. M. V.; FASSANI, E. J.; TEIXEIRA, A. S.; PEREIRA, E. S. Avaliação de fontes de cálcio para frangos de corte. Revista Caatinga, Mossoró, v. 20, n. 1, p. 5-14, 2007.

OLIVEIRA, A. F. G.; BRUNO, L. D. G.; GARCIA, E. R. M.; LEITE, M. C. P.; TON, A. P. S.; LORENÇON, L. Efeito da densidade de criação e do grupo genético sobre o desempenho e o desenvolvimento ósseo de frangos de corte. Scientia Agraria Paranaenis, Marechal Cândido Rondon, v. 11, n. 1, p. 49-64, 2012.

OLIVEIRA, M. C.; BENTO, E. A.; CARVAlHO, F. I.; RODRIGUES, S. M. M. Características da cama e desempenho de frangos de corte criados em diferentes densidades populacionais e tipos de cama. ARS Veterinária, Jaboticabal, v. 21, n. 3, p. 303-310, 2005.

PILECCO, M.; ALMEIDA PAZ, I. C. L.; TABALO, L. A.; NAAS, I. A.; GARCIA, R. G.; CALDARO, C. R.; ALVES, M. C. F.; CAUCHIOLO, F. Manejo para redução de arranhões dorsais em frangos de corte. Revista Agrarian, Dourados, v. 4, n. 14, p. 359-366, 2011.

POLCARO-SILVA, M. T. Desempenho e características de carcaça de três genótipos comerciais de frango de corte alimentados com diferentes dietas. 2013. Dissertação (Mestrado em Zootecnia) - Faculdade de Ciências Agrárias, UFVJM Vale do Jequitinhonha e Murici, Diamantina.

PONSO, R.; FARIA, D. E.; ALBURQUERQUE, R.; PAZ, C. L. A.; ARTONI, S. M. B.; SANTOS, A. L.; SAVIANE, G.; ARAÚJO, C. M. M. Avaliação do desenvolvimento da discondroplasia tibial em frangos de corte submetidos à dieta com 25 hidroxicolecalciferol. Brazilian Journal of Veterinary Research and Animal Science, São Paulo, v. 49, n. 2, p. 153-161, 2012.

ROSTAGNO, H. S. Tabelas brasileiras para aves e suínos: composição de alimentos e exigências nutricionais. 3. ed. Viçosa, MG: UFV, Departamento de 
Zootecnia, 2011. 252 p.

SAKOMURA, N. K.; ROSTAGNO, H. S. Métodos de pesquisa em nutrição de monogástricos. Jaboticabal: Funep, 2007. 283 p.

SANTOS, A. L.; SAKOMURA, N. K.; FREITAS, E. R.; FORTE, C. M. L. S.; CARRILHO, E. N. V. M.; FERNANDES, J. B. K. Estudo do crescimento, desempenho, rendimento de carcaça e qualidade de carne de três linhagens de frango de corte. Revista Brasileira de Zootecnia, Jaboticabal, v. 34, n. 5, p. 1589-1598, 2005.

SEEDOR, J. G.; QUARTUCCIO, H. A.; THOMPSON, D. D. The biophosphonate alendronate $(\mathrm{MK}-217)$ inhibit bone loss due to ovariectomy in rats. Journal of Bone and Mineral Research, Washington, v. 6, n. 4, p. 339346, 1991. 
